\title{
ANALYSIS OF WATER QUALITY OF THE MEGHNA RIVER USING MULTIVARIATE ANALYSES AND RPI
}

\author{
MD. SIMUL BHUYAN ${ }^{1 *}$, MUHAMMAD ABU BAKAR $^{2}$, AYSHA AKHTAR $^{1}$, \\ M. BELAL HOSSAIN ${ }^{3}$ AND MD. SHAFIQUL ISLAM ${ }^{1}$ \\ ${ }^{1}$ Institute of Marine Sciences and Fisheries, University of Chittagong, Chittagong, Bangladesh \\ ${ }^{2}$ Bangladesh Council of Scientific and Industrial Research, Chittagong, Bangladesh \\ ${ }^{3}$ Noakhali Science and Technology University, Noakhali, Bangladesh
}

\begin{abstract}
The present study was carried out to measure the physico-chemical variables of surface water of the Meghna River from September 2015 to March 2016. Air temperature, water temperature, soil $\mathrm{pH}$, water $\mathrm{pH}, \mathrm{DO}, \mathrm{BOD}_{5}, \mathrm{COD}$, TSS, TDS, $\mathrm{PO}_{4}-\mathrm{P}, \mathrm{NO}_{3}-\mathrm{N}$ and $\mathrm{EC}$ concentrations in water samples were found to range from $14-29^{\circ} \mathrm{C}, 11-28^{\circ} \mathrm{C}, 5.9-6.9$, 7.2-7.5, 4.2-6.71 mg/L, 0.67-3.71 mg/L, 2.5-5.9 mg/L, 8-20 mg/L, 72-130 mg/L, 0.11$0.90 \mu \mathrm{g} / \mathrm{l}, 0.115-0.90 \mu \mathrm{g} / \mathrm{l}$ and $115.8-220 \mu \mathrm{Scm}^{-1}$ respectively. River Pollution Index (RPI) indicated that the water of river at impacted site was less to moderately polluted. Unimpacted site was also less polluted as per RPI and mostly used for agriculture. Correlation Matrix (CM) and Multivariate statistical analyses namely Cluster Analysis (CA), Principal Component Analysis (PCA) and Factors Analysis (FA) indicated that river water was polluted. The principal causes of the pollution of the river were haphazard industrialization, domestic sewage and agricultural inputs. Using of river water can pose serious problems to human health by biological food chain. This research suggests to proper management of the river with eco-friendly industrialization and urbanization for sustainable development of the country.
\end{abstract}

Key words: Water quality, Physico-chemical parameters, River pollution index, Industrialization, Meghna River

\section{Introduction}

Water, the most essential and important compound for all living creatures that form ecosystems (Manjare et al. 2010 and Kataria et al. 2011). Water quality can be assessed by its physical, chemical and biological properties (Manjare et al. 2010). This water delivers multiple uses for innumerable rural and urban communities and livestock, fish culture, recharge of ground water, control of floods etc. (Gurunathan and Shanmugam 2006). The quality of water is being degraded continuously due to haphazard industrialization (Manjare et al. 2010). Principally, the term industrialization is related with socio-economic activities (Thanoon et al. 2003, Richard 2005 and Jaillon and Poon 2009) that are basically responsible for the modification of the society setup (Abdullah $e t$ al. 2009) through the enormous production (Thanoon et al. 2003 and Abdullah et al. 2009). Most probably the effects of industrialization is in the state of beggar description on the aquatic biota. These may affect man unswervingly or through the provisions of water, agricultural ingredient and other biological products, the most common source of pollutants frequently discharged from domestic and industrial sectors. Chemicals produced from industries are a major source of water pollution that carried through 
geological materials may cause problems (Kataria et al. 2011). Most of the industries are major contributor of trace metals. According to the WHO up to $80 \%$ of all illness and ailment in the world is triggered by poor sanitation and contaminated water (Budhathoki 2010). Least developed countries like Bangladesh, facing serious problems with water contaminations from different industries, domestic wastes and agrochemicals (Venugopal et al. 2009 and Islam et al. 2015a and b).

The main aim of this study was the assessment of water quality to report the baseline data of the area that will be useful in future to measure any anthropogenic contamination level.

\section{Materials and Methods}

Sampling Sites: Meghna River near Narsingdi Sadar is used as a river Ghat to move in various directions from Narsingdi District by cluster of wood made engine boats awaiting for passengers. The launch terminal is just steps away from this Ghat. There are a lot of textile mills and textile-related industries nearby. Moreover, dying industries and jute industries are also occupying in the catchment area. Therefore, the sources of pollution are various. Phosphorus in wastewater comes from food, pesticides, and industries (Site1). Nitrates in wastewater originate from ammonia being converted to nitrates by bacteria in the treatment process. Chemicals that are known human endocrine disruptors include diethylstilbesterol (the drug DES), dioxin, PCBs, DDT, and some other pesticides. Annual rainfall in the area is about $1,329 \mathrm{~mm}$. The surrounding is mostly used for agriculture where various types of pesticides e.g. DDT, Algin, Organophosphates are widely used (Site-2).

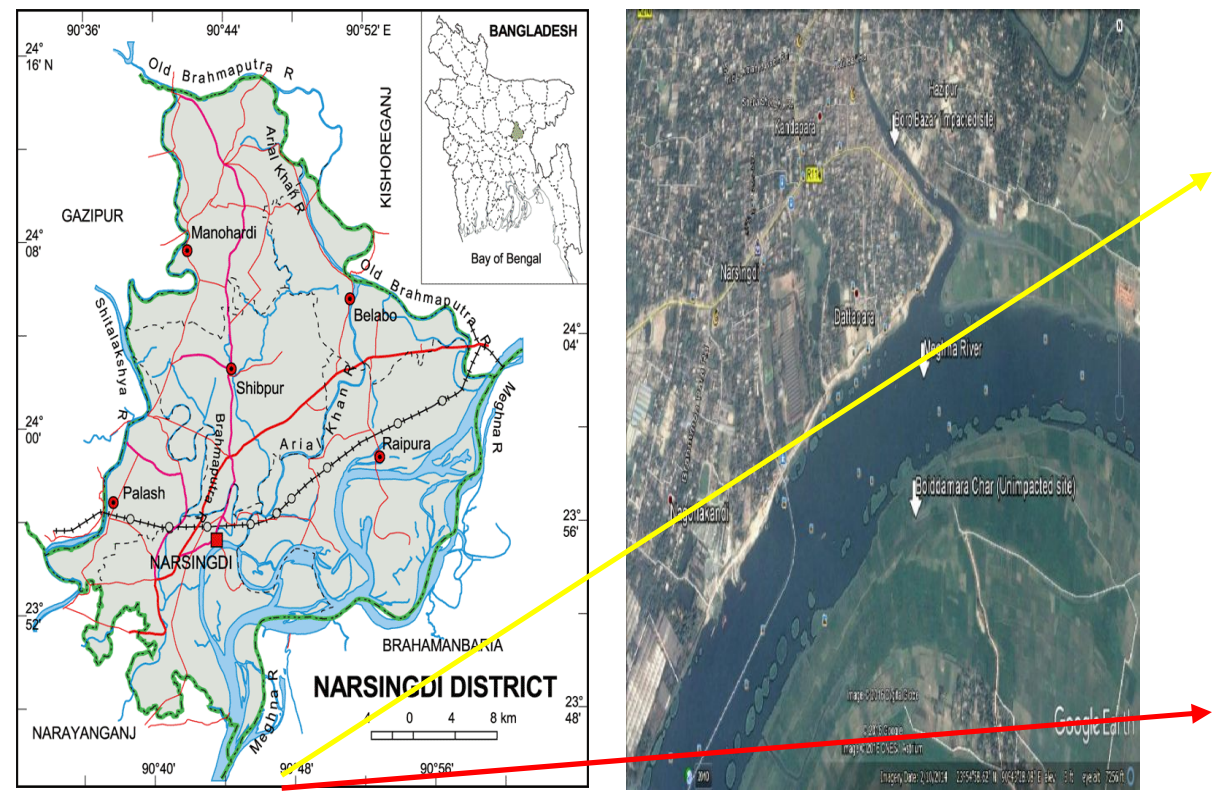

Fig. 1. Map showing sampling points of the Meghna River. 
Water samples were collected from two points: 1. Effluent discharge area (Boro Bazar) and 2. far away from the discharged area (Boiddamar Char) of the Meghna River near Narsingdi District (Fig. 1). Sampling procedures were performed in three phases: firstly, September, 2015 (Rainy season); secondly, January, 2016 (Winter season) and thirdly, March, 2016 (Pre-monsoon).

Sample Collection and Preservation: After selection of sampling points, a total of 12 water samples was collected. 6 water samples were collected from industrial impacted site and rest 6 samples were collected from the pristine area $(3 \mathrm{~km}$ far from industrial zone). 2 liters of surface water sample were collected in the morning hours between 10 to $11 \mathrm{am}$, in polythene bottle regularly for every seasons. Immediately after collection, water sample were transferred to the laboratory of Bangladesh Council of Scientific and Industrial Research (BCSIR), Chittagong. $\mathrm{pH}$, temperature and dissolved oxygen were measured from studied sites during sampling of water.

Sample Analysis: Water temperature was measured by a glass Celsius thermometer. Total suspended solid analyzed by the method stated by EPA (1979). The value of Hydrogenion-Concentration $(\mathrm{pH})$ of water was determined by using $\mathrm{pH}$ paper (color $\mathrm{pH}$ indicators strips, Cat.9585, made in Germany). To determine the Dissolve Oxygen (DO) the collected samples in BOD bottles were fixed inside according to Azide Modification of Winkler (1988) and analyses were made by the same method. Bio-chemical Oxygen Demand (BOD), Chemical Oxygen Demand (COD), Total Dissolved Solid (TDS), Nitrate-N $\left(\mathrm{NO}_{3}-\mathrm{N}\right)$, Phosphate-P $\left(\mathrm{PO}_{4}-\mathrm{P}\right)$ were analyzed by the method stated by APHA (2005).

Statistical Analysis: One Way Analysis of Variance ((Post-hoc LSD test) was done to show the variations in concentration of water parameters in terms of seasons and sites using SPSS (v.22). According to Dreher (2003), Principal Component Analysis (PCA) was performed on the original data set (without any weighting or standardization). Component Analysis (CA) is an effective tool to find out the similarity and variation with the influencing factors on different data sets (Wang et al. 2014). Moreover, CA is an important tool for the characterization and simplification of data sets with the behavior they possess. PCA was executed to sort out the principle features of variations in dataset with simplification and classification of raw data. According to Singh et al. (2004), PCA delivers strategies on spatial and temporal distribution of resultant factors. Pearson's product moment correlation matrix was done to identify the relation among parameters to make the result strong obtained from multivariate analysis. Cluster analysis (Dendogram) was performed to show the similarity among variables and to identify their sources of origin using PRIMER (v.6).

\section{Results and Discussion}

Water Temperature: Water temperature plays a significant role that influences the chemical, bio-chemical features of water body. The highest temperature was recorded $28^{\circ} \mathrm{C}$ during pre-monsoon and lowest was recorded $11^{\circ} \mathrm{C}$ during winter. The results found 
to be similar with Simpi et al. (2011). Salve and Hiware (2008) reported that water temperature in pre-monsoon was high due to low water level, high temperature and clear atmosphere.

Table 1. Physico-chemical parameters of water at two sampling points during 3 seasons.

\begin{tabular}{|c|c|c|c|c|c|c|c|c|c|c|c|c|}
\hline \multirow[b]{2}{*}{ Parameters } & \multirow[b]{2}{*}{ Seasons } & \multirow[b]{2}{*}{$\begin{array}{l}\text { Air } \\
\text { temperature } \\
\left({ }^{\circ} \mathrm{C}\right)\end{array}$} & \multirow[b]{2}{*}{$\begin{array}{l}\text { Water } \\
\text { temperature } \\
\left({ }^{\circ} \mathrm{C}\right)\end{array}$} & \multicolumn{3}{|c|}{ Parameters } & \multirow[b]{2}{*}{$\begin{array}{l}\mathrm{BOD}_{5} \\
(\mathrm{mg} / \mathrm{L})\end{array}$} & \multirow[b]{2}{*}{$\begin{array}{l}\mathrm{COD} \\
(\mathrm{mg} / \mathrm{L})\end{array}$} & \multirow[b]{2}{*}{$\begin{array}{l}\mathrm{TSS} \\
(\mathrm{mg} / \mathrm{L})\end{array}$} & \multirow[b]{2}{*}{$\begin{array}{l}\text { TDS } \\
(\mathrm{mg} / \mathrm{L})\end{array}$} & \multirow[b]{2}{*}{$\begin{array}{l}\mathrm{PO}_{4-} \\
\mathrm{P}(\mu \mathrm{g} / \mathrm{l})\end{array}$} & \multirow[b]{2}{*}{$\begin{array}{l}\mathrm{NO}_{3}-\mathrm{EC} \\
\mathrm{N} \quad \mu \mathrm{Scm} \\
\left.(\mu \mathrm{g} / \mathrm{l})^{1}\right)\end{array}$} \\
\hline & & & & $\begin{array}{l}\text { Soil } \\
\mathrm{pH}\end{array}$ & $\begin{array}{l}\text { Water } \\
\mathrm{pH}\end{array}$ & $\begin{array}{l}\mathrm{DO} \\
(\mathrm{mg} / \mathrm{L})\end{array}$ & & & & & & \\
\hline $\begin{array}{l}\text { Impacted } \\
\text { site }\end{array}$ & Rainy & 29 & 25 & 5.9 & 7.5 & 4.7 & 3.23 & 5.9 & 20 & 130 & 0.11 & 0.135210 \\
\hline $\begin{array}{l}\text { Unimpacted } \\
\text { site }\end{array}$ & & 21 & 23 & 6.1 & 7.2 & 6.71 & 0.75 & 2.5 & 12 & 80 & 0.90 & 0.115127 .3 \\
\hline $\begin{array}{l}\text { Impacted } \\
\text { site }\end{array}$ & Winter & 18 & 11 & 6.9 & 7.2 & 4.2 & 3.67 & 5.6 & 23 & 120 & 0.75 & 0.125189 .7 \\
\hline $\begin{array}{l}\text { Unimpacted } \\
\text { site }\end{array}$ & & 14 & 12 & 6.9 & 7.5 & 4.71 & 0.67 & 2.65 & 8 & 72 & 0.78 & 0.90 \\
\hline $\begin{array}{l}\text { Impacted } \\
\text { site }\end{array}$ & $\begin{array}{l}\text { Pre- } \\
\text { monsoon }\end{array}$ & 31 & 28 & 6.8 & 7.3 & 4.3 & 3.71 & 5.4 & 25 & 122 & 0.78 & 0.124220 \\
\hline $\begin{array}{l}\text { Unimpacted } \\
\text { site }\end{array}$ & & 29 & 26 & 6.9 & 7.4 & 4.56 & 3.61 & 3.01 & 10 & 75 & 0.80 & 0.122135 .9 \\
\hline
\end{tabular}

Air Temperature: The temperature in 3 consecutive seasons of different sampling points fluctuated between $(14-31)^{\circ} \mathrm{C}$ due to the influence of environmental temperature. Maximum temperature $\left(31^{\circ} \mathrm{C}\right)$ was recorded from impacted site during pre-monsoon and minimum $\left(14^{\circ} \mathrm{C}\right)$ was found in unimpacted site during winter. Dalal et al. (2013) recorded $26^{\circ} \mathrm{C}$ at the Dham River and Manjare et al. (2010) found $25^{\circ} \mathrm{C}$ at Tamdalge tank, Kolhapur district, Maharashtra.

Hydrogen-ion-Concentration (pH): Roy (1955), Moore (1972), APHA (2005), Mahmood and Bhuyian (1988), Sarma et al. (1982) and Campbell (1978) stated that the industrial or municipal waste materials had a significant role in increasing or decreasing $\mathrm{pH}$ of the adjacent water body where the waste materials were dumped. Air temperature is the prime responsible factor for changing the $\mathrm{pH}$ of water. Furthermore, bio-chemical and chemical reactions are influenced by the $\mathrm{pH}$ (Manjare et al. 2010). In the present study, the results indicate that the water of the river slightly alkaline (7.2-7.5) in nature. This report strictly agreed with the Farshad and Venkataramana (2012).

Dissolve Oxygen (DO): In the present study, the dissolve oxygen was recorded to be between (4.2-6.71) $\mathrm{mg} / \mathrm{L}$ in sampling site. The highest DO recorded was $6.71 \mathrm{mg} / \mathrm{L}$ during rainy season. More or less similar observations were also recorded by Khan et al. (1976), Bhuyian (1979), Hossain et al. (1988), Mahmood and Bhuyian (1988), Hossain and Khan (1992), Jashimuddin and Khan (1993), Islam and Khan (1993), Alam et al. (1996) and Gasim et al. (2007). 
Bio-chemical Oxygen Demand (BOD): Paul (1999) mentioned that, river water having BOD more than $10 \mathrm{mg} / \mathrm{L}$ is considered to be moderately and more than $20 \mathrm{mg} / \mathrm{L}$ as to be highly contaminated water. In the present study, the BOD was found to range from 0.67$3.71 \mathrm{mg} / \mathrm{L}$. More or less similar result was observed by Kataria et al. (2011) at Bhopal city water whereas higher BOD was recorded by Sikder et al. (2016) at the Turag River.

Chemical Oxygen Demand (COD): COD varied from (2.5-5.9) $\mathrm{mg} / \mathrm{L}$ in the present study. Those results are far below than the results found by Sikder et al. (2016), Ahmed and Nizamuddin (2012) and Miah (2012). Higher BOD harmful to all aquatic life and can cause a substantial damage to submersed plants (Nian et al. 2007). Like BOD, higher COD is also harmful to all aquatic life.

Total Dissolved Solid (TDS): In the present study, the total dissolved solids fluctuated from $(72-130) \mathrm{mg} / \mathrm{L}$. The maximum value $(130 \mathrm{mg} / \mathrm{L})$ was recorded during rainy season at industrial polluted site. It is due to heavy rainfall of the season (Manjare et al. 2010) and minimum value $(72 \mathrm{mg} / \mathrm{L})$ was found during winter at unimpacted site.

Nitrate- $N\left(\mathrm{NO}_{3}-\mathrm{N}\right)$ : The values of nitrate ranges from $0.115 \mu \mathrm{g} / \mathrm{l}$ to $0.90 \mu \mathrm{g} / \mathrm{l}$. The highest value $(0.90 \mu \mathrm{g} / \mathrm{l})$ was observed during winter at unimpacted site and lowest $(0.115 \mu \mathrm{g} / \mathrm{l})$ during rainy season at unimpacted site. Hasan et al. (2009) found $0.18 \mathrm{mg} / \mathrm{L}$ and 0.02 $\mathrm{mg} / \mathrm{L}$ nitrite-nitrogen at the Buriganga and Panguchi River.

Phosphate- $P\left(\mathrm{PO}_{4}-\mathrm{P}\right)$ : The value of phosphate fluctuates from $(0.11-0.90) \mu \mathrm{g} / \mathrm{l}$. the maximum value $(0.90 \mu \mathrm{g} / \mathrm{l})$ was recorded during rainy season at unimpacted site and minimum value $(0.11 \mu \mathrm{g} / \mathrm{l})$ was recorded during rainy season at impacted site. This results fully acquiesced with results found by Manjare et al. (2010). The high values of phosphate recorded during monsoon might be due to rain, surface water runoff and agriculture run off (Manjare et al. 2010).

Spatial and Temporal Changes in Water Quality Parameters: Significant variations were found for air temperature, water temperature and soil $\mathrm{pH}$ with seasons as the significance level ( $\mathrm{p} \leq 0.05$ ) but water $\mathrm{pH}, \mathrm{DO}, \mathrm{BOD}, \mathrm{COD}$, TSS, TDS, $\mathrm{PO}_{4}-\mathrm{P}, \mathrm{NO}_{3}-\mathrm{N}$ and EC showed no significant variations with seasons $(\mathrm{p} \geq 0.05)$. Furthermore, prevalent variations were found for COD, TSS, TDS and EC with sites as the alpha level $(\mathrm{p} \leq 0.05)$. No significant variations was found for air temperature, water temperature, soil $\mathrm{pH}$, water $\mathrm{pH}, \mathrm{DO}$, $\mathrm{BOD}, \mathrm{PO}_{4}-\mathrm{P}$ and $\mathrm{NO}_{3}-\mathrm{N}(\mathrm{p} \leq 0.05)$ with sites (Fig. 2). 


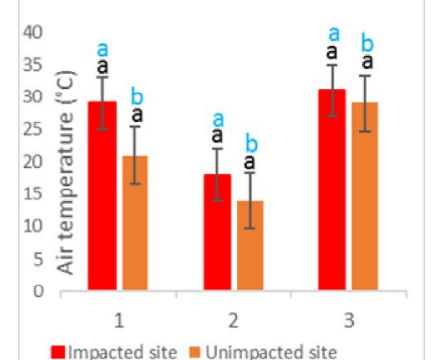

Impacted site n Unimpacted site

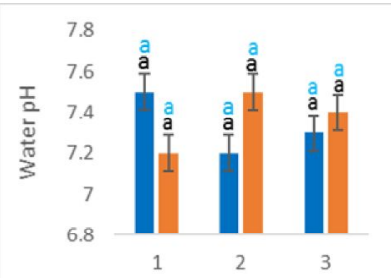

- Impacted site In Unimpacted site

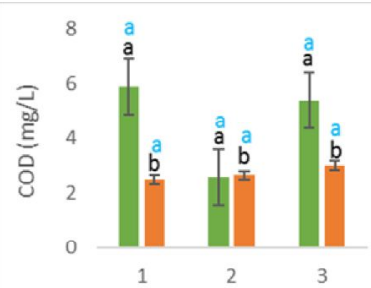

- Impacted site Unimpacted site

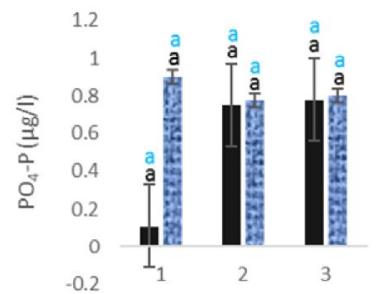

- Impacted site Unimpacted site
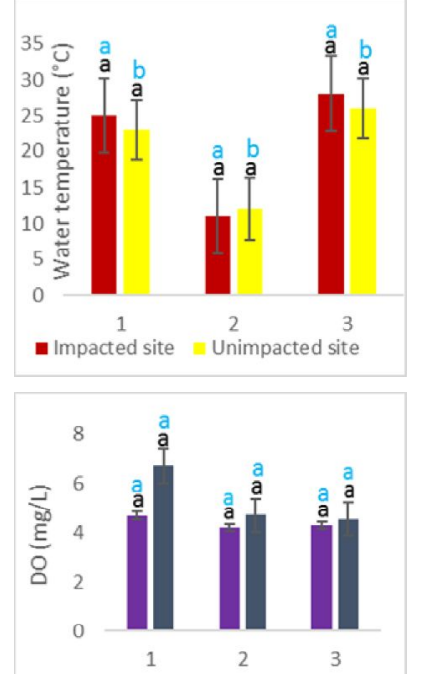

- Impacted site unimpacted site

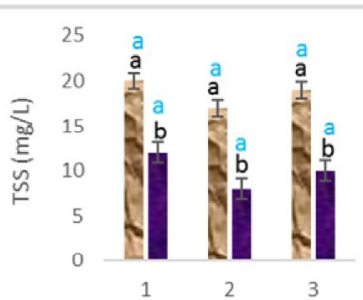

- Impacted site Unimpacted site

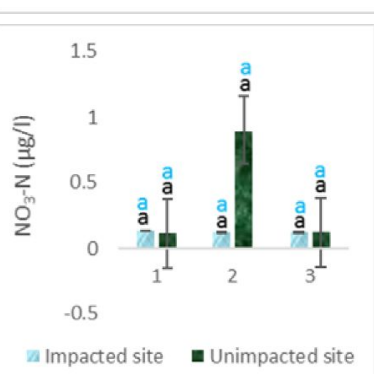

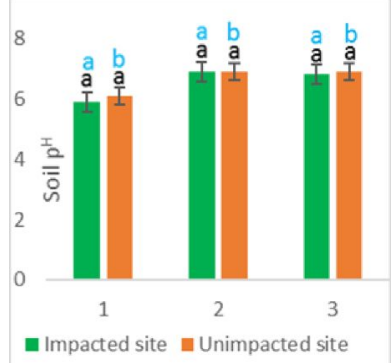

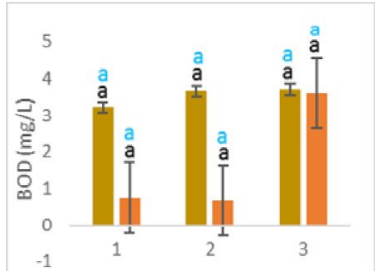

Impacted site $=$ Unimpacted site
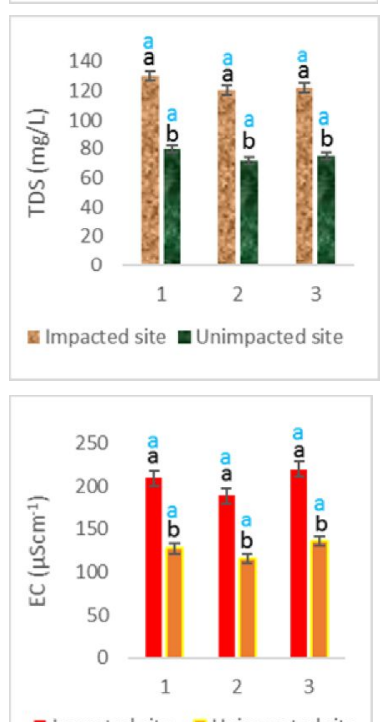

- Impacted site = Unimpacted site

Fig. 2. Variations $(M e a n \pm S D)$ of water quality variables. Bars with the same letter are statistically indifferent.

1= Rainy season, $2=$ Winter season, $3=$ Pre-monsoon

Black $a \& b=$ Variation with sites, Blue $a \& b=$ Variation with seasons. 
Cluster Analysis: Different multivariate statistical analyses viz: Cluster Analysis (CA), Principal Component Analysis (PCA) and Factors Analysis (FA) act as fruitful guide for eloquent explanation of spatio-temporal parametric data. Many scholars have used these methods to evaluate and categorized the water quality. Wang et al. (2014) used these statistical analyses for the depict interpretation of the water chemistry. Furthermore, Talukder et al. (2016); Wang et al. (2012), Jiang-Qu et al. (2013), Venkastesharaju et al. (2010), Qadir et al. (2007) and Kowlkowski et al. (2006) stated that multivariate statistical methods (PCA, CA, FA) can be very effective tools for easy and clear interpretation of the complex data sets, recognizing pollution factors and assessing water quality parameters with spatio-temporal deviation.

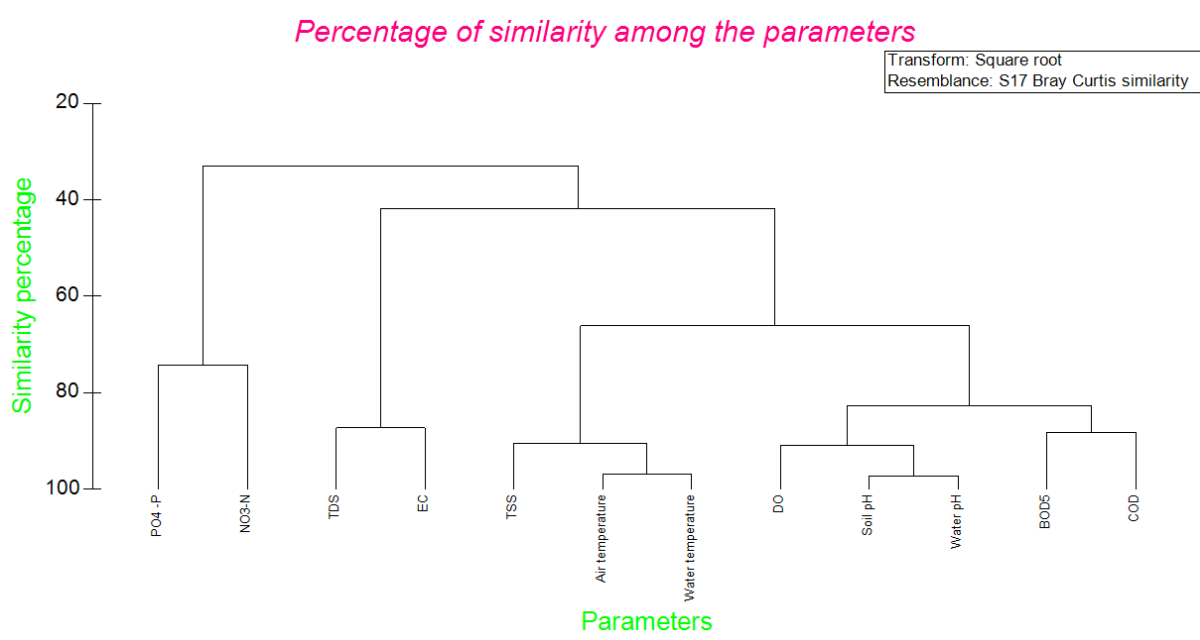

Fig. 3. Dendogram showing the percentage of similarity among parameters during different seasons at impacted site. (TSS=Total Dissolve Solid; $\mathrm{BOD}=\mathrm{Bio}-\mathrm{Chemical}$ Oxygen Demand; $\mathrm{COD}=$ Chemical Oxygen Demand; EC=Electrical Conductivity; DO=Dissolve Oxygen; TDS=Total Dissolved Solid)

Cluster analyses (CA) were executed using square root and Bray Curtis Similarity to show the similarity among the parameters that contribute hugely in water pollution. From the output of the cluster analysis total three clusters were found at impacted site during different seasons. Cluster 1 include: $\mathrm{PO}_{4}-\mathrm{P}$ and $\mathrm{NO}_{3}-\mathrm{N}$; Cluster 2: TDS and EC; cluster 3: TSS, Air temperature and Water temperature; cluster 4: DO, Soil $\mathrm{pH}$ and Water $\mathrm{pH}$; cluster 5: $\mathrm{BOD}_{5}$ and COD (Fig. 3).

$\mathrm{PO}_{4}-\mathrm{P}$ and $\mathrm{NO}_{3}-\mathrm{N}$ represent strong linkage with minimum cluster distance that indicate those parameters have influencing power during seasonal variations. Parameters grouped together in less distance have higher affinity with similar identical behavior during temporal variations and also exert a probable effect to each other. Furthermore TDS and EC have also strong linkage but lesser than cluster 1 but contribute largely in environmental process. TSS, Air temperature and Water temperature were under the group of cluster 3 with minimum distance than cluster 1 and cluster 2 but have effects on environment. DO, Soil $\mathrm{pH}$ and Water $\mathrm{pH}$ formed cluster 4 but exert less influence than 
cluster 1,2 and cluster $3 . \mathrm{BOD}_{5}$ and $\mathrm{COD}$ formed cluster 5 and have less effects on environment than cluster 1, 2, 3 and 4. Impacted site is the effluents discharged area of the river which highly affected by untreated industrial effluents, agricultural inputs and domestic wastes. Unimpacted area is located far from the effluents discharged area that can be treated as less polluted area.

Correlation Matrix: In river water environment, the inter linkage among water parameters deliver noteworthy information sources and pathways of parameters. The results of correlation between water parameters fully consented with the results obtained by PCA and CA that approve some new associations between variables. Very strong positive linear relationships were found between COD vs TDS (0.984), TSS vs TDS (0.981), TDS vs EC (0.971), TSS vs EC (0.969), COD vs EC (0.961), COD vs TSS (0.939), air temperature vs water temperature (0.919) (Table 3). Strong positive correlations were recorded between BOD vs Ec (0.747), BOD vs COD (0.741), air temperature vs BOD (0.667), BOD vs TDS (0.658), BOD vs TSS (0.642) and $\mathrm{PO}_{4}-\mathrm{P}$ vs Soil $\mathrm{pH}$ (0.603) (Table 3). Moreover moderate positive linear relations were found between air temperature vs $\mathrm{EC}(0.583)$, Water $\mathrm{pH}$ vs $\mathrm{NO}_{3}-\mathrm{N}(0.546)$, air temperature vs TSS (0.536), air temperature vs TDS (0.426) and air temperature vs COD (0.411) (Table $3)$. The very strong, strong and moderate correlations indicate that the parameters were originated from similar sources particularly from industrial effluents, domestic wastes and agricultural inputs. Besides, strong negative correlations were found between DO vs BOD (-0.708), $\mathrm{NO}_{3}-\mathrm{N}$ vs Air temperature (-0.673), BOD vs $\mathrm{NO}_{3}-\mathrm{N}(-0.632)$, TDS vs $\mathrm{PO}_{4}-\mathrm{P}(-0.616), \mathrm{COD}$ vs $\mathrm{PO}_{4}-\mathrm{P}(-0.614)$ and $\mathrm{TSS}$ vs $\mathrm{NO}_{3}-\mathrm{N}(-0.608)$ in river water.

Table 3. Correlation matrix of physico-chemical parameters in river water.

\begin{tabular}{|c|c|c|c|c|c|c|}
\hline & & $\begin{array}{c}\text { Air } \\
\text { temperature }\end{array}$ & $\begin{array}{l}\text { Water } \\
\text { emperature }\end{array}$ & Soil pHWater $\mathrm{pH}$ & BOD COD TSS TDS $\mathrm{PO}_{4}-\mathrm{PNO}_{3}-\mathrm{N}$ & $\mathrm{EC}$ \\
\hline \multirow{12}{*}{ 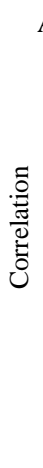 } & Air temperature & 1.000 & & & & \\
\hline & $\begin{array}{c}\text { Water } \\
\text { temperature }\end{array}$ & 0.919 & 1.000 & & & \\
\hline & Soil pH & -0.246 & -0.390 & 1.000 & & \\
\hline & Water $\mathrm{pH}$ & 0.104 & 0.068 & -0.079 & & \\
\hline & DO & -0.195 & 0.163 & -0.331 & 1.000 & \\
\hline & BOD & 0.667 & 0.334 & -0.081 & -0.7081 .000 & \\
\hline & COD & 0.411 & 0.097 & -0.047 & $-0.591 \mathbf{0 . 7 4 1} 1.000$ & \\
\hline & TSS & 0.536 & 0.320 & -0.174 & $-0.316 \mathbf{0 . 6 4 2} \mathbf{0 . 9 3 9} 1.000$ & \\
\hline & TDS & 0.426 & 0.162 & -0.111 & $-0.447 \mathbf{0 . 6 5 8} \mathbf{0 . 9 8 4 0 . 9 8 1} 1.000$ & \\
\hline & $\mathrm{PO}_{4}-\mathrm{P}$ & -0.361 & -0.200 & -0.571 & $0.259-0.307-0.61-0.59-0.6161 .000$ & \\
\hline & $\mathrm{NO}_{3}-\mathrm{N}$ & -0.673 & -0.583 & 0.546 & $-0.093-0.632-0.45-0.61-0.4950 .141 \quad 1.000$ & \\
\hline & EC & 0.583 & 0.321 & -0.092 & $-0.512 \mathbf{0 . 7 4 7} 0.9610 .9690 .971-0.539-0.533$ & 1.000 \\
\hline
\end{tabular}

(At the significance level of 0.05 ).

Green color indicates very strong positive correlation.

Red color indicates strong positive correlation.

Blue color indicates moderate positive correlation. 
Principal Component Analysis: The extraction method was used in PCA analysis that was Eigen values. The components were regarded as principal components whose Eigen values were greater than 0.6. Principal component highlighted the most vital factors that affect the water quality of the study area. PC1 had a highest initial Eigen value 6.06 and total variance $50.5 \%$, with strong positive loading of EC, TSS, TDS, COD, BOD and air temperature, moderate positive loading of water temperature and moderate negative loading of $\mathrm{NO}_{3}-\mathrm{N}, \mathrm{PO}_{4}-\mathrm{P}$ and $\mathrm{DO}$ resembled the loading of pollution mainly caused by untreated organic load with crucial anthropogenic effect (Table 4). PC 2 had Eigen value 2.32 and explained $19.3 \%$ of total variance, with strong positive loading of soil $\mathrm{pH}$, high negative loading of DO and water temperature can be represented as effect of geological changes on environmental parameters. PC 3 explained 15.5 percent of total variance, with strong positive loading of $\mathrm{PO}_{4}-\mathrm{P}$. Strong negative loading of water $\mathrm{pH}$ and $\mathrm{NO}_{3}-\mathrm{N}$. The total variance of the PC4 was $12.1 \%$. PC4 strongly correlated with Water temperature and Air temperature. From the present PCA study, it may be concluded that the source of PC 1 and PC 2 can be mixed source from anthropogenic inputs particularly from industrial wastes and agricultural actions in the study area. While the source of PC 3 and PC 4 can be considered as different source like lithogenic and anthropogenic inputs.

Table 4. Component matrix of four factors model with strong to moderate loadings in river water.

\begin{tabular}{ccccc}
\hline & \multicolumn{4}{c}{ Component } \\
& 1 & 2 & 3 & 4 \\
\hline EC & 0.961 & 0.140 & & -0.122 \\
TSS & 0.948 & & & -0.287 \\
TDS & 0.927 & 0.156 & & -0.325 \\
COD & 0.923 & 0.298 & & -0.244 \\
BOD & 0.817 & 0.260 & 0.315 & 0.322 \\
Air temperature & 0.720 & -0.381 & & 0.576 \\
NO $_{3}-\mathrm{N}$ & -0.670 & 0.510 & -0.454 & \\
DO & -0.458 & -0.829 & & -0.317 \\
Soil pH & -0.276 & 0.719 & 0.524 & 0.357 \\
Water temperature & 0.461 & -0.657 & & 0.563 \\
Water pH & & 0.271 & -0.850 & 0.451 \\
PO ${ }_{4}-\mathrm{P}$ & -0.627 & & 0.743 & \\
Eigen value & 6.06 & 2.32 & 1.86 & 1.45 \\
\% Total variance & 50.5 & 19.3 & 15.5 & 12.1 \\
Cumulative $\%$ & 50.5 & 69.8 & 85.8 & 97.4 \\
\hline
\end{tabular}

River Pollution Index (RPI): In recent time, River pollution index (RPI) simple method is used concurrently by different organization like Taiwan EPA to assess the surface water quality. This method comprising with concentration level of four parameters: DO, BOD, $\mathrm{SS}$, and $\mathrm{NH}_{3}-\mathrm{N}$. Pollution status is calculated using four-state of each parameter. The RPI is computed using following equation (Liou et al. 2004):

$$
\mathrm{RPI}=1 / 4 \sum_{\mathrm{i}=1}^{4} \mathrm{Si}
$$


Table 5. River Pollution Index (RPI) Chart (Chen et al. 2012 and Liou et al. 2004).

\begin{tabular}{lllll}
\hline Items/ ranks & Good & Less polluted & Moderately polluted & Highly polluted \\
$\mathrm{DO}(\mathrm{mg} / \mathrm{L})$ & $>6.5$ & $4.6-6.5$ & $2.0-4.5$ & $<2.0$ \\
$\mathrm{BOD}_{5}(\mathrm{mg} / \mathrm{L})$ & $<3.5$ & $3.0-4.9$ & $5.0-15$ & $>15$ \\
$\mathrm{SS}(\mathrm{mg} / \mathrm{L})$ & $<2.0$ & $20-49$ & $50-100$ & $>100$ \\
$\mathrm{NH}_{3}-\mathrm{N}(\mathrm{mg} / \mathrm{L})$ & $<0.5$ & $0.5-0.9$ & $91.0-3.0$ & $>3.0$ \\
Index scores $(\mathrm{Si})$ & 1 & 3 & 6 & 10 \\
Sub-index & $<2$ & $2.0-3.0$ & $3.1-6.0$ & $>6.0$ \\
\hline
\end{tabular}

In present study, the concentrations of $\mathrm{DO}, \mathrm{BOD}_{5}$ and $\mathrm{TSS}$ were compared with concentrations of RPI table to weigh the status of particular water variables (Table 1). Average DO in the impacted site was found to be $4.7 \mathrm{mg} / \mathrm{L}$ during rainy season that indicate the water is less polluted in comparison with RPI but the water of unimpacted site contained $4.2 \mathrm{mg} / \mathrm{L} \mathrm{DO}$ that is the of good water. Averages DO in the impacted site was recorded $4.7 \mathrm{mg} / \mathrm{L}$ during winter season which can be treated as moderately polluted zone according to RPI index while $4.71 \mathrm{mg} / \mathrm{L}$ DO was found from the unimpacted site that direct the area is less polluted. During pre-monsoon the average DO concentration was recorded $4.3 \mathrm{mg} / \mathrm{L}$, which designate moderate pollution in this area according to RPI table. Where $4.56 \mathrm{mg} / \mathrm{L}$ was found from unimpacted area that also renders the area characterized with less pollution. Average amount of $\mathrm{BOD}_{5}$ were found between (3.23$3.71) \mathrm{mg} / \mathrm{L}$ for all seasons at the impacted site indicating that the water of the river is less polluted according to (Table 5). The mean concentration was recorded for $\mathrm{BOD}_{5} 3.61$ $\mathrm{mg} / \mathrm{L}$ during pre-monsoon at unimpacted area indicating the water is less polluted but the other two season's concentrations indicate that the water of unimpacted area is good. Average TSS for every seasons were found between (20-49) $\mathrm{mg} / \mathrm{L}$ at impacted area that is a clue of less pollution according to RPI. At unimpacted site the average concentrations of TSS were recorded below (20-49) $\mathrm{mg} / \mathrm{L}$ that indicate the water is good.

From the present findings it may be concluded that the water of the river is being polluted day by day due to unplanned industrialization, urbanization and agricultural activities. Using of river water for domestic, irrigation and pisciculture purposes might cause great harm to human being. Moreover, the risky concentrations of some water parameters can pose great risk to fish and human community dwelling in and adjacent to the Meghna River. Lately, the present research is giving preference on the better management of the river water to protect the health of riverine ecosystem.

\section{Acknowledgements}

The authors are thankful to the Bangladesh Council of Scientific and Industrial Research (BCSIR), Chittagong. The proposed research is a key contribution of Biodiversity, Environment and Climate Change Research Laboratory, Institute of Marine Sciences and Fisheries, University of Chittagong. 


\section{References}

Abdullah, M. R., K. A. Mohd Kamar, M. N. Mohd Nawi, A. Tarmizi Haron and M. Arif. 2009. Industrialized building system: A definition and concept." Proc. of ARCOM Conference 2009, Notingham, UK.

Ahmed, M. J and M. Nizamuddin. 2012. Physicochemical Assessment of Textile Effluents in Chittagong Region of Bangladesh and Their Possible Effects on Environment. Inter. J of Res. in Chemis. Environ. 2: 220-230.

Alam, M. M., M. A. Islam, S. Islam and S.Z. Haider. 1996. Surface water quality of various polluted locations. J Bangladesh Chemi. Soci. 8: 129-137.

APHA (American Public Health Association). 2005. Standard Methods for the examination of water and waste water, $13^{\text {th }}$ edition Broadway, New York.

Bhuyian, A.M. 1979. Effect of industrial pollution on the biology of the Karnafully River. M. Phil Thesis, Deparment of Zoology, University of Chittagong, $164 \mathrm{pp}$.

Budhathoki, R. 2010. Analysis of the physico-chemical and bacteriological parameters of bottled water available in Kathmandu valley, A Case Study on the Partial Fulfillment of the Requirements for M.Sc., First Year, Environment Science, T.U.

Campbell, I.C. 1978. A biological investigation of an organically polluted urban stream in Victoria. Austr. J of Mari. Fresh. Res. 29: 275-91.

Chen, Y.C., H.C. Yeh and C. Wei. 2012. Estimation of river pollution index in a tidal stream using Kriging analysis. Int. J. Environ. Res. Public Heal. 9: 3085-3100.

Dalal, L.P., S.P. Kalbende and R.S. Nisal. 2013. Physico-chemical Assessment of Water Quality of River and the Hydro-biological Study of Algae. Inter. J of Sci. Eng. Res. 4: 1-10.

Dreher, T. 2003. Evaluation of graphical and multivariate methods for classification of water chemistry data. Hydro. J. 11: 605-606.

Enviromental Protection Agency (EPA), 1976. Quality Criteria for Water', United States Environmental Protection Agency (EPA), pp. 123-127.

Farshad, H. and G.V. Venkataramana. 2012. Impact of Physico-Chemical Parameters of Water on Zooplankton Diversity in Nanjangud Industrial Area, India. Inter. Res. Journal of Environ. Sci. 1: 37-42.

Gasim, M.B., B.S. Ismail, E. Toriman, S.I. Mir and T.C. Chek. 2007. A Physico-chemical Assessment of the Bebar River, Pahang, Malaysia. Glo. J Environ. Res. 1: 7-11.

Gurunathan, A. and C.R. Shanmugam. 2006. Customary Rights and their Relevance in Modern Tank Management: Select Cases in Tamil Nadu, Paper prepared for the workshop entitled 'Water, Law and the Commons' organized in Delhi from 8 to 10 December 2006 by the International Environmental Law Research Centre (ILERC).

Hasan, I., S. Rajia, K.A. Kabir and G.A. Latifa, 2009. Comparative Study on the Water Quality Parameters in Two Rural and Urban Rivers Emphasizing on the Pollution Level. Global J. Environ. Res. 3: 218-222.

Hossain, M.M., N. Mahmood and A.L. Bhuyian. 1988. Some water quality characteristics of the Karnafuli River estuary. J. of the Asiatic soci. Bang. 21: 183-188.

Hossain, T. and Y.S.A. Khan. 1992. Study on the Environment Impact Assessment (EIA) of the effluent discharge of the Chittagong Urea Fertilizer Limited (CUFL) on the Karnafuli River estuary. M. Sc. Thesis, Institute of Marine Sciences, University of Chittagong.

Islam, M.S., M.K. Ahmed, M. Habibullah-Al-Mamun and M.F. Hoque. 2015a. Preliminary assessment of heavy metal contamination in surface sediments from a river in Bangladesh. Environ. Earth Sci. 73: 1837-1848.

Islam, M.S., M.K. Ahmed, M. Raknuzzaman, M. Habibullah-Al-Mamun and M.K. Islam. 2015b. Heavy metal pollution in surface water and sediment: a preliminary assessment of an urban river in a developing country. Ecolog. Indica. 48: 282-291.

Islam, M.M. and Y.S.A. Khan. 1993. Study on the influence of the effluent discharged by the KPM and KRC on the physiochemical parameters of the Karnafully River, Chittagong. M. Sc. Thesis, Institute of Marine Sciences, University of Chittagong. 
Jaillon, L. and C.S. Poon. 2009. The evolution of prefabricated residential building systems in Hong Kong: A review of the public and the private sector. Automation in Const. 18: 239248.

Jashimuddin, S.M. and Y.S.A. Khan. 1993. Environmental Impact Assessment (EIA) of the municipal sewage discharge through majhirghat canal on the Karnafuli River water, Chittagong. M. Sc. Thesis, Institute of Marine Sciences, University of Chittagong.

Jiang-Qi, Q., Z., Qing-Jing, L., Pan, J. Cheng-Xia, and Y. Mu. 2013. Assessment of Water Quality Using Multivariate Statistical Methods: A Case Study of an urban Landscape Water, Beijing. Int. J. Biosci. Biochem. Bioinforma. 3: 196-200.

Kataria, H.C. M., Gupta, M. Kumar, S. Kushwaha, Kashyap, S. S. Trivedi, R. Bhadoriya and N.K. Bandewar. 2011. Study of Physico-chemical Parameters of Drinking Water of Bhopal city with Reference to Health Impacts. Current W. Environ. 6: 95-99.

Khan, Y.S.A., Mahmood, N., Quader, O. Bhuyian, A.L and M.K. Ahmed. 1976. Studies on the hydrology of the Karnafuli estuary. J of the Asiatic soci. Bang. 2: 89-99.

Kowalkowski, T., R. Zbytniewski, J. Szpejna and B. Buszewski. 2006. Application of chemo metrics in water classification. Water Res. 40: 744-752. http://dx.doi.org/ 10.1016 /j.watres.2005.11.042

Liou, S.M., Lo, S.L. and S.H. Wang. 2004. A generalized water quality index for Taiwan. Environ. Monit. Assess. 96: 35-52.

Mahmood, N. and A.M. Bhuyian. 1988. Some water quality characteristic of the Karnafuli River estuary. Mahassagar Bull. Nati Inst. Sci. Ind. 22: 183-188.

Manjare, S.A., S.A. Vhanalakar and D.V. Muley. 2010. Analysis of water quality using physicochemical parameters Tamdalge tank in Kolhapur district, Maharashtra. Inter. J Advan. Biotech. Res. 1: 115-119.

Moore, P. 1972. Studies on the pollution of the Bhadra River fisheries and Bhadravathi (Mysore state) with industrial effluents. Nat. Inst. Sci. Ind. 22: 132-160.

Miah, M.S. 2012. Cost-effective Treatment Technology on Textile Industrial Wastewater, in Bangladesh. J of Che. Eng. 27: 32-36.

Nian, Y.G., Q.J., Xu, X.C., Jin, C.Z., Yan, J. Liu, Jiang. 2007. Effects of chitosan on growth of an aquatic plant (Hydrilla verticillata) in polluted waters with different chemicaloxygen demands. J. of Environ. Sci. 19: 217.

Paul, G. 1999. Environment and Pollution, Poribes Dushan (Ed), Dasgupta and Company Ltd, India. Pp. 323.

Qadir, A., R.N. Malik and S.Z. Husain. 2007. Spatio-temporal variations in water quality of NullahAik-tributary of the river Chenab, Pakistan. Environ. Monit. Assess. 140: 43-59.

Richard, R.B. 2005. Industrialized building systems: Reproduction before automation and robotics. Automation in Const. 14: 442-451.

Roy, H.K. 1955. Plankton ecology of the River Hoogly in Patna. West Bengal. Eco. 36: 169-175.

Salve, V.B. and C.J. Hiware. 2008. Study on water quality of Wanparakalpa reservoir Nagpur, Near Parli Vaijnath, District Beed. Marathwada region. J. Aqua. Biol. 21: 113-117.

Sarma, V.V., G.R.K. Raju, and T.R. Babu. 1982. Pollution characteristics and water quality in the Visakhapatnam harbour. Mahassagar Bull. Nati. Inst. Oce. 15: 15-22.

Sikder, M.N.A, S.M.S. Huq, M.A.A. Mamun, K.A. Hoque, M.S. Bhuyan and M.A. Bakar. 2016. Assessment of physicochemical parameters with its effects on human and aquatic animals giving special preference to effective management of Turag River. J. of Environ. Sci. Toxico. Food Tech. 10: 41-51.

Simpi, B., S.M. Hiremath, K.N.S. Murthy, K.N. Chandrashekarappa, A.N. Patel and E.T. Puttiah. 2011. Analysis of Water Quality Using Physico-Chemical Parameters Hosahalli Tank in Shimoga District, Karnataka, India. Glo. J of Sci. Front. Res. 11: 1-5.

Singh, K.P., A. Malik, D. Mohan and S. Sinha. 2004. Multivariate statistical techniques for the evaluation of spatial and temporal variations in water quality of Gomti River (India) - a case study. Wat. Res. 38: 3980-3992. 
Talukder, A., D. Mallick, T. Hasin, I.Z. Anka and M.M. Hasan. 2016. Spatio-temporal variability in hydro-chemical characteristics of coastal waters of Salimpur, Chittagong along the Bay of Bengal. J. Fish. 4: 335-344.

Thanoon, W.A., L. Wah Peng, M.R. Abdul Kadir, M.S. Jaafar and M.S. Salit. 2003. The essential characteristics of industrialized building system." Proc. of International Conference on Industrialized Building Systems, Kualalumpur, Malaysia, pp. 283-292.

Venkatesharaju, K., R.K. Somashekar and K.L. Prakash. 2010. Study of seasonal and special variation in surface water quality of Cauvery river stretch in Karnataka. J. Ecol. Nat. Environ. 2:1-9.

Venugopal, T., L. Giridharan and M. Jayaprakash. 2009. Characterization and Risk Assessment Studies of Bed Sediments of River Adyar-An Application of Speciation Study. Inter. J Environ. Res. 3: 581-598.

Wang, X., Q., Cai, L. Ye and X. Qu. 2012. Evaluation of spatial and temporal variation in stream water by multivariate statistical techniques: A case study of the Xiangxi River basin, China. Quarter. Inter. 1: 1-8.

Wang, Y.B., C.W. Liu, P.Y. Liao and J.J. Lee. 2014. Spatial pattern assessment of river water quality: implications of reducing the number of monitoring stations and chemical parameters. Environ. Monit. Assess. 186: 1781-1792.

Winkler, L.W. 1988. The determination of dissolved oxygen in Water. Berlin. Deut. Chem. yeas. 21.2845 Nov; 133.

(Revised copy received on 6/6/2017) 